\title{
Anorthite porcelain: synthesis, phase and microstructural evolution
}

\author{
MOUSUMI PAL ${ }^{1}$, SUKHEN DAS ${ }^{2}$ and SWAPAN KUMAR DAS ${ }^{1, *}$ \\ ${ }^{1}$ Refractory Division, CSIR - Central Glass and Ceramic Research Institute, Kolkata 700 032, India \\ ${ }^{2}$ Physics Division, Jadavpur University, Kolkata 700 032, India
}

MS received 10 October 2013; revised 2 June 2014

\begin{abstract}
In the present study, anorthite $\left(\mathrm{CaAl}_{2} \mathrm{Si}_{2} \mathrm{O}_{8}\right)$ porcelain was fabricated using $\mathrm{Ca}(\mathrm{OH})_{2}, \mathrm{Al}(\mathrm{OH})_{3}, \mathrm{quartz}$, aluminous cement and feldspar as raw materials. Two compositions were formulated (coded as CAQ and CFQ) and their physico-mechanical properties (\% AP, BD, flexural strength) were studied and compared. CAQ (21.2 wt \% $\mathrm{Ca}(\mathrm{OH})_{2}, 44.5 \mathrm{wt} \% \mathrm{Al}(\mathrm{OH})_{3}$ and $34.3 \mathrm{wt} \%$ quartz) shows very poor densification and strength even after heating at $1450^{\circ} \mathrm{C}$, although anorthite formation is observed on heating it at various temperatures. On the other hand, CFQ (48.6 wt\% aluminous cement, $29.37 \mathrm{wt} \%$ feldspar and $22.06 \mathrm{wt} \%$ quartz) achieved full densification and superior strength at $1450^{\circ} \mathrm{C}$ with more anorthite formation compared to $\mathrm{CAQ}$. X-ray diffraction and scanning electron microscope studies were also carried out to analyse the phase and microstructure evolution. The coefficient of thermal expansion of the anorthite-based sample was found to be lower than quartz and mullite porcelain which suggests its application as cooking ware.
\end{abstract}

Keywords. Porcelain; anorthite; mechanical properties.

\section{Introduction}

Anorthite $\left(\mathrm{CaO} \cdot \mathrm{Al}_{2} \mathrm{O}_{3} \cdot 2 \mathrm{SiO}_{2}\right)$ which is the lime-rich end member of plagioclase feldspar series, $\left[\mathrm{Na}\left(\mathrm{AlSi}_{3} \mathrm{O}_{8}-\right.\right.$ $\left.\mathrm{Ca}\left(\mathrm{Al}_{2} \mathrm{Si}_{2} \mathrm{O}_{8}\right)\right]$, has great potential as a ceramic material for electronic substrate applications because of its low thermal expansion coefficient $\left(4.82 \times 10^{-6 \circ} \mathrm{C}^{-1}\right)$, high thermal shock resistance and low dielectric constant $\left(\varepsilon_{\mathrm{r}} \sim 6.2\right.$ at $1 \mathrm{MHz}){ }^{1,2}$ For these excellent characteristics, anorthite porcelain has good use in electronic industries, industrial heat exchangers and biomedical materials. ${ }^{3,4}$ Anorthite has low refractive index value of 1.58 , which is close to that of glass phase 1.51 and it has density $2.75 \mathrm{~g} \mathrm{~cm}^{-3}$. Due to this low relative refractive index anorthite ceramic has own excellent property of translucency which is comparable with bone china. ${ }^{5}$ At elevated temperatures, the plagioclase series forms an essentially solid solution from pure albite $\left[\mathrm{Na}\left(\mathrm{AlSi}_{3} \mathrm{O}_{8}\right)\right]$ to pure anorthite. Six divisions in this series give the mineral names albite, oligoclase, andesine, labradorite, bytownite and anorthite. ${ }^{1-4}$ During passing from albite to anorthite some changes in its crystallographic structure occur and crystallization of anorthite in microstructure increases material strength, chemical stability and density. ${ }^{2}$ Many processes have been developed to produce anorthite porcelain. Aluminous cement $\left(\mathrm{CaO} \cdot \mathrm{Al}_{2} \mathrm{O}_{3}\right.$ and $\left.\mathrm{CaO} \cdot 2 \mathrm{Al}_{2} \mathrm{O}_{3}\right)$, limestone $\left(\mathrm{CaCO}_{3}\right)$, colemanite $\left(2 \mathrm{CaO} \cdot 3 \mathrm{~B}_{2} \mathrm{O}_{3} \cdot 5 \mathrm{H}_{2} \mathrm{O}\right)$, wollastonite $\left(\mathrm{CaO} \cdot \mathrm{SiO}_{2}\right)$, calcite $\left(\mathrm{CaCO}_{3}\right)$ and dolomite $\left(\mathrm{CaCO}_{3} \cdot \mathrm{MgCO}_{3}\right)$ can all be used in the production of anorthite-based porcelains as a $\mathrm{CaO}$ source. $^{2,5-8}$ Gdula $^{1}$ prepared anorthite which were suitable

*Author for correspondence (swapan@cgcri.res.in) for dielectric applications from inexpensive raw materials kaolinite and $\mathrm{CaCO}_{3}$. Shanjun $\mathrm{Ke}$ et $a l^{8}$ prepared anorthitebased porcelains by using three different $\mathrm{CaO}$ sources including dolomite, wollastonite and calcite and the microstructure and property of porcelain were affected by different $\mathrm{CaO}$ sources. The authors reported that in all the samples anorthite was the primary crystalline phase at optimum sintering temperature. In case of calcite only anorthite was formed while in case of wollastonite small amount of corundum was formed due to higher content of $\mathrm{Al}_{2} \mathrm{O}_{3}$ in sample containing wollastonite than calcite. Again sample containing wollastonite showed highest flexural strength $(110 \mathrm{MPa}){ }^{8}$ Mergena and Aslanolu ${ }^{7}$ introduced boron oxide as additive along with the raw materials (kaolinite, quartz and calcite) for lowering sintering temperature. The authors observed that no single phase formed in boron-free samples even at sintering temperature. However in boron containing samples, anorthite was formed with $87 \%$ theoretical density at a lower temperature with some minor phases like gehlenite and quartz. But at sintering temperature $\left(1000-1100^{\circ} \mathrm{C}\right)$ only anorthite was reported. It was also reported that boron-containing samples showed higher density as expected. ${ }^{7}$ Tai et $a l^{6}$ produced anorthite porcelain using non-plastic raw materials such as feldspar, quartz and aluminous cement which has a high green strength due to hydration reaction of aluminous cement with feldspar and low density due to formation of anorthite during firing. In the fired body $\alpha$-quartz, anorthite, glass and a small amount of $\alpha-\mathrm{Al}_{2} \mathrm{O}_{3}$ were formed. Crystoballite was only formed with higher quartz content. ${ }^{6}$ The present authors also prepared anorthite porcelain from inorganic solid wastes and other ceramic materials. But the authors observed 
that along with anorthite some other crystalline phases were also formed such as enstatite, fayalite, mullite and quartz. $^{9,10}$

In the present study, the authors aim to prepare anorthite phase only from the mineral raw materials such as quartz, feldspar and highly pure chemicals. Properties such as bulk density, porosity, phase, microstructures and flexural strength were investigated and reported in detail.

\section{Experimental}

\subsection{Materials}

The starting materials include $\mathrm{Ca}(\mathrm{OH})_{2}, \mathrm{Al}(\mathrm{OH})_{3}$ (Merck), quartz, feldspar [Hyderabad, India] and aluminous cement (Secar 71). Aluminous cement, feldspar and quartz were analysed by standard method. ${ }^{11}$

\subsection{Methods}

2.2a Sample preparation: Two batches (CAQ and CFQ) were prepared as per the composition provided in table 1 . The raw materials were mixed separately according to batches and milled for $5 \mathrm{~h}$ by pot milling process with water. After drying the slip at $110-120^{\circ} \mathrm{C}$ for $24 \mathrm{~h}$, green samples $\left(60 \times 14 \times 5 \mathrm{~mm}^{3}\right)$ were fabricated from the powders by hydraulic compaction at a pressure of $350 \mathrm{~kg} \mathrm{~cm}^{-2}$. CAQ samples were fabricated using $5 \%$ dilute solution of PVA binder. The addition of PVA binder in case of CAQ was necessary as this composition contain all non-plastic materials. CFQ samples were fabricated using 5\% water as binder because this composition contain high aluminous cement which contribute strength development at green stage itself. The green samples were dried in air and then in an oven for $24 \mathrm{~h}$ at $110-120^{\circ} \mathrm{C}$. Finally the samples were fired in the temperature range $1200-1450^{\circ} \mathrm{C}$ with a soaking period of $30 \mathrm{~min}$. The heating rate was $5^{\circ} \mathrm{C} \mathrm{min}^{-1}$ upto $800^{\circ} \mathrm{C}$ and then $3^{\circ} \mathrm{C} \min ^{-1}$ upto the highest temperature.

2.2b Measurement of physico-mechanical properties: The physical characteristics (\%AP, BD, flexural strength) of the fired samples were measured. AP and BD were measured by the water displacement method following the Archimedes principle and flexural strength was measured by INSTRON 5500R (three-point bending method). Thermal expansion

Table 1. Raw materials used in batch composition (wt \%).

\begin{tabular}{lcc}
\hline Raw materials & CAQ & CFQ \\
\hline $\mathrm{Ca}(\mathrm{OH})_{2}$ & 21.2 & - \\
$\mathrm{Al}(\mathrm{OH})_{3}$ & 44.5 & - \\
Quartz & 34.3 & 22.06 \\
Aluminous cement & - & 48.56 \\
Feldspar & - & 29.37 \\
\hline
\end{tabular}

coefficient of the fired samples was measured by dilatometer (NETZSCH 402C).

2.2c X-ray diffraction (XRD) characterization XRD study of the samples was performed to identify the phases formed. The XRD pattern of the samples were recorded in an X'Pert Pro MPD diffractometer (PAN Analytical) using an $\mathrm{X}^{\prime}$ Celerator operating at $40 \mathrm{kV}$ and $30 \mathrm{~mA}$ using Ni-filtered $\mathrm{CuK} \alpha$ radiation. The weight percentage of crystalline and amorphous phases were measured by Rietveld analysis ${ }^{12,13}$ by X'pert high score plus software (Pan Analytical; www. Minweb.co.uk and www.PANanalytical.com) using a known amount of highly crystalline calcium fluoride as internal standard.

2.2d Scanning electron microscope (SEM) characterization: For SEM study, the samples were grounded with $\mathrm{SiC}$ powder and water. Then the samples were polished with 6 , 3 and $1 \mu \mathrm{m}$ diamond paste, respectively. The polished samples of each sample were chemically etched for $30 \mathrm{~s}$ in $10 \%$ $\mathrm{HF}$ solution at room temperature and washed with water and acetone. Finally the secondary electron image of the polished gold-coated surface of the samples were taken using SEM (LEO 430i).

\section{Results}

\subsection{Chemical analysis of the raw materials}

The chemical analysis of quartz and feldspar are given in table 2 and it is found to be of normal quality generally used to prepare porcelain product. Aluminous cement containing $\mathrm{CaO}$ and $\mathrm{Al}_{2} \mathrm{O}_{3}$ equivalent to monocalcium aluminate.

\subsection{Densification study and flexural strength measurement}

The variation in \% AP and BD of the samples heated at different temperatures is given in figures 1 and 2 , respectively. It may be observed that the samples heated at 1200 and $1300^{\circ} \mathrm{C}$ possess very high porosity $(>50 \%)$ and no densification is achieved at this two temperatures. The flexural strength (figure 3 ) in these temperatures revealed very poor strength $(<6 \mathrm{MPa})$. But as the temperature increases to $1400^{\circ} \mathrm{C}$ some densification is noticed with the slight improvement in strength and porosity. It is very interesting to observe that in case of CFQ, the samples heated at $1450^{\circ} \mathrm{C}$ shown enhanced densification $\left(>2.30 \mathrm{~g} \mathrm{~cm}^{-3}\right.$ ) approaching density of pure anorthite porcelain $\left(2.75 \mathrm{~g} \mathrm{~cm}^{-3}\right)$. A significant improvement in strength $(>70 \mathrm{MPa})$ is also observed with the porosity level in the range $(<2.0 \%)$. This may be due to the higher reactivity of presynthesized aluminous cement $\left(\mathrm{CaO} \cdot \mathrm{Al}_{2} \mathrm{O}_{3}\right)$. In addition, aluminous cement as a substitute of clay in triaxial porcelain composition will also give adequate green strength due to its hydraulic properties. The similar beneficial effect of aluminous cement is observed by Tai et al ${ }^{6}$ towards formation of anorthite porcelain. In case of $\mathrm{CAQ}$, although 
Table 2. Chemical composition of the raw materials.

\begin{tabular}{lrrrrrrrrrr}
\hline Constituent & $\mathrm{SiO}_{2}$ & $\mathrm{Al}_{2} \mathrm{O}_{3}$ & $\mathrm{Fe}_{2} \mathrm{O}_{3}$ & $\mathrm{TiO}_{2}$ & $\mathrm{CaO}$ & $\mathrm{MgO}$ & $\mathrm{SO}_{3}$ & $\mathrm{Na}_{2} \mathrm{O}$ & $\mathrm{K}_{2} \mathrm{O}$ & $\mathrm{L} . \mathrm{O} . \mathrm{I}$. \\
\hline Feldspar & 67.01 & 18.13 & 0.24 & $\mathrm{Nil}$ & 1.03 & 0.23 & - & 1.69 & 11.03 & 0.54 \\
Quartz & 97.99 & 0.39 & 0.07 & 0.01 & 0.10 & 0.02 & - & 0.09 & 0.12 \\
Aluminous cement & 0.30 & 68.00 & 0.18 & 0.10 & 30.95 & 0.10 & 0.10 & 0.12 & 0.08 & - \\
\hline
\end{tabular}

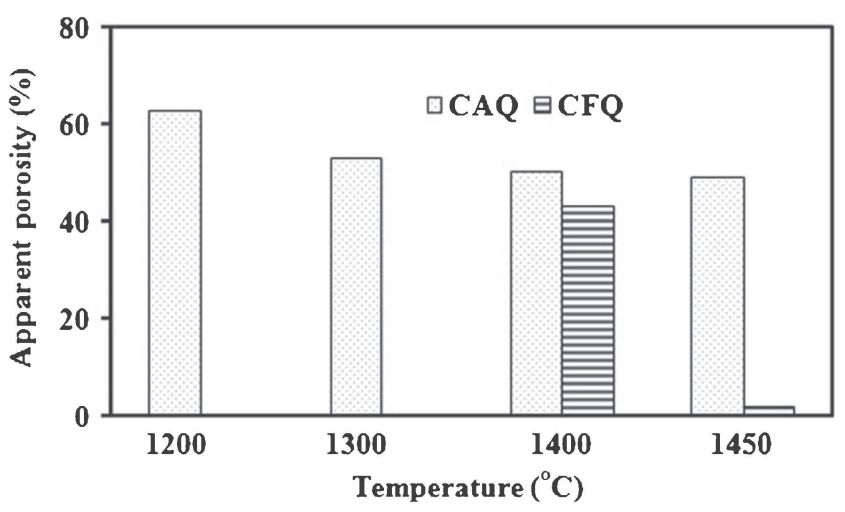

Figure 1. Variation of apparent porosity of the heated samples at different temperatures.

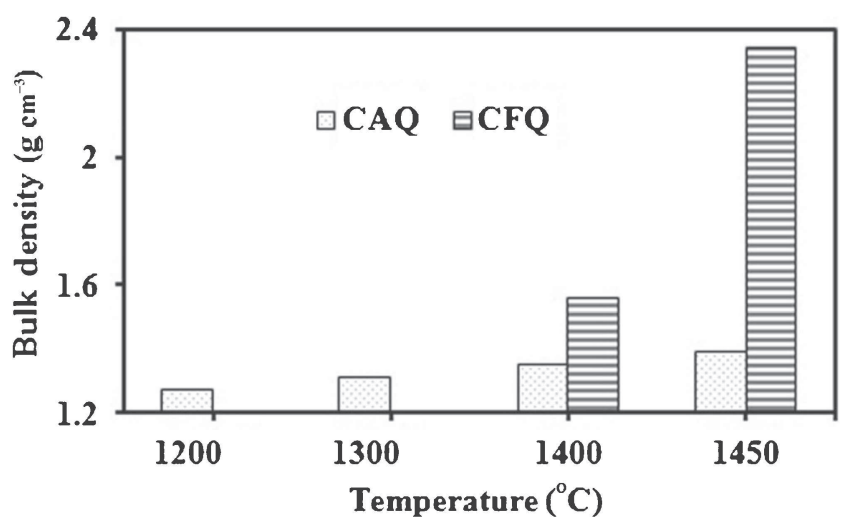

Figure 2. Variation of bulk density of the heated samples at different temperatures.

$\mathrm{Ca}(\mathrm{OH})_{2}$ and $\mathrm{Al}(\mathrm{OH})_{3}$ having high surface area but to form anorthite $\left(\mathrm{CaAl}_{2} \mathrm{Si}_{2} \mathrm{O}_{8}\right)$ it may require higher temperature for effective reaction followed by densification.

The coefficient of thermal expansion of vitrified CFQ sample was measured and the value was found to be $4.5 \times 10^{-6}$ ${ }^{\circ} \mathrm{C}^{-1}$ which is less than quartz and alumina porcelain (table 3 ). With this low coefficient of thermal expansion value, anorthite porcelain is expected to have better thermal shockresistant property than other type of porcelain. The improved heat stability of such type of porcelain suggests its application as cooking wares.

\subsection{XRD study}

The XRD pattern of the samples heated at 1400 and $1450^{\circ} \mathrm{C}$ are separately provided in figures 4 and 5 for $\mathrm{CAQ}$ and

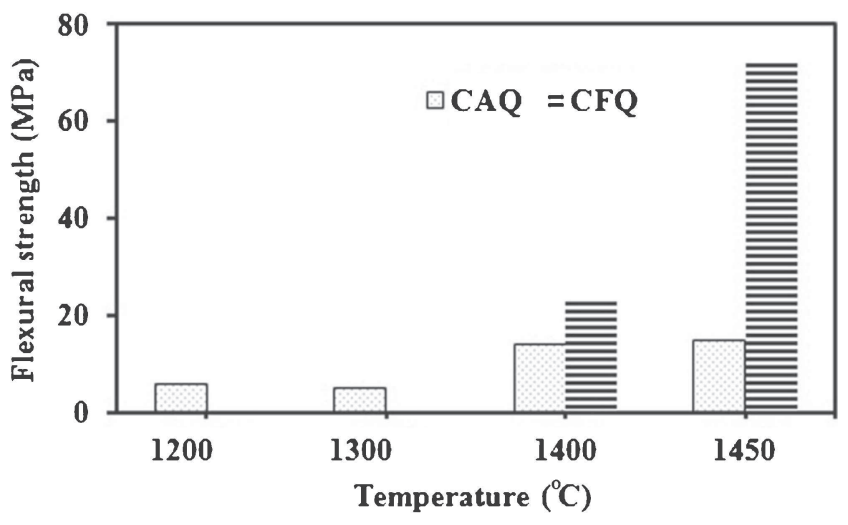

Figure 3. Variation of flexural strength of the heated samples at different temperatures.

Table 3. Thermal expansion coefficient values of different kinds of porcelain $\left(\mathrm{RT}-650^{\circ} \mathrm{C}\right)$.

\begin{tabular}{lc}
\hline Porcelain type & Thermal expansion coefficient $\left(/{ }^{\circ} \mathrm{C} \times 10^{-6}\right)$ \\
\hline Quartz porcelain & $6-8^{14}$ \\
Alumina porcelain & $5-7^{14}$ \\
Anorthite porcelain & $4.82,{ }^{1} 4.5$ (obtained in CFQ) \\
\hline
\end{tabular}

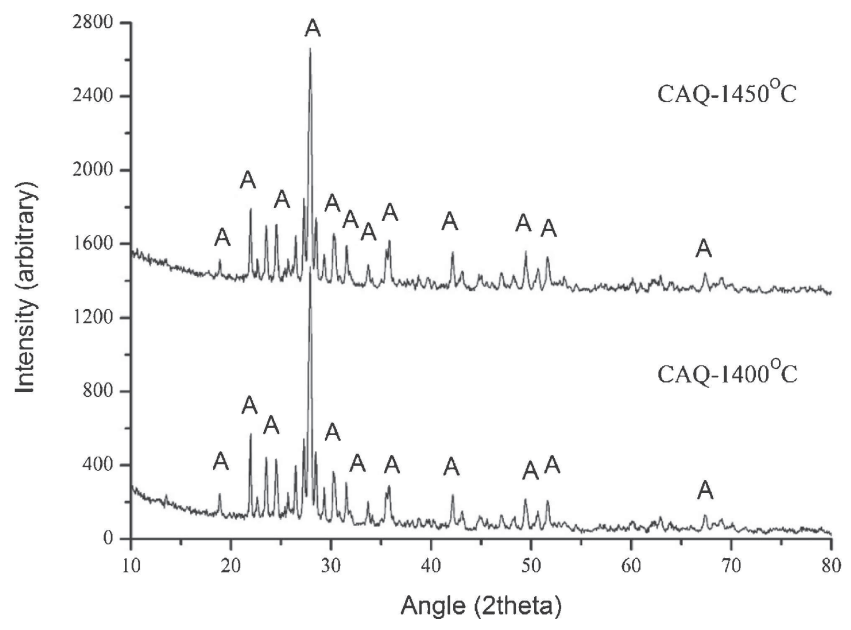

Figure 4. XRD pattern of the sample CAQ at two different temperatures 1400 and $1450^{\circ} \mathrm{C}$.

CFQ, respectively. There is no major change observed in their XRD patterns at these two temperatures for both the 
samples and all the peaks are identified as anorthite crystals. The quantitative estimation of crystalline and amorphous

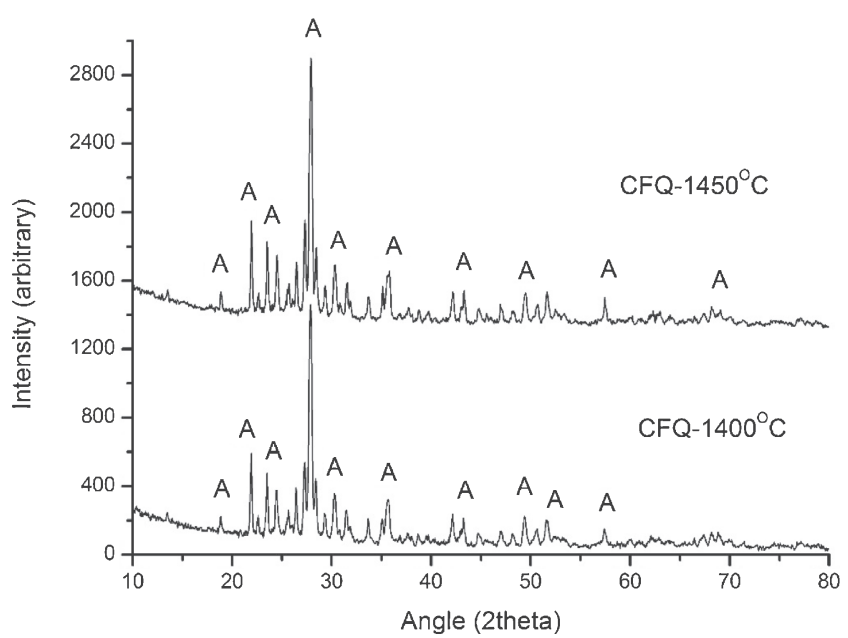

Figure 5. XRD pattern of the sample CFQ at two different temperatures 1400 and $1450^{\circ} \mathrm{C}$.

Table 4. Weight percentage of crystalline and amorphous phases.

\begin{tabular}{lcccc}
\hline \multirow{2}{*}{$\begin{array}{l}\text { \%wt of crystal- } \\
\text { line phases }\end{array}$} & \multicolumn{4}{c}{ Sample mark } \\
\cline { 2 - 5 } & CAQ 1400 & CAQ 1450 & CFQ 1400 & CFQ 1450 \\
\hline Amorphous & 48.50 & 47.90 & 39.50 & 37.40 \\
Crystalline & 51.50 & 52.10 & 60.50 & 62.60 \\
\hline
\end{tabular}

phases are provided in table 4 . It may be observed that the wt $\%$ of the amorphous and crystalline phases in CAQ and CFQ is almost similar. However it may be seen that in case of CFQ, the crystalline phase in more than amorphous phase and also it is higher than CAQ at $1450^{\circ} \mathrm{C}$. The same authors synthetically produced anorthite from a combination of inexpensive solid wastes materials such as LD slag, BF slag and fly ash. However, such wastes incorporated body formed other phases such as fayalite, mullite, enstatite along with anorthite as identified by these authors. ${ }^{9,10}$

\subsection{SEM study}

The SEM images of the fractured surface of $1450^{\circ} \mathrm{C}$ heated samples chemically etched with $10 \% \mathrm{HF}$ solution for $30 \mathrm{~s}$ are shown in figures 6 and 7. Figure $6 a$ and $b$ shows characteristic octahedral anorthite crystals in sample CAQ. Shanjun $\mathrm{Ke} e t a l^{8}$ also observed similar kind of grain morphology when dolomite, wallostonite and calcite were used as sources of $\mathrm{CaO}$. Marques and Tulyaganov ${ }^{15}$ used the system $\mathrm{CaF}_{2}-\mathrm{CaO}-\mathrm{Al}_{2} \mathrm{O}_{3}-\mathrm{SiO}_{2}-\mathrm{MgO}-\mathrm{P}_{2} \mathrm{O}_{5}-\mathrm{B}_{2} \mathrm{O}_{3}$ and fabricated anorthite crystal with similar shape but at lower temperature range of $850-950^{\circ} \mathrm{C}$. Figure 6c shows the SEM image at lower magnification of the same sample.

Figure $7 \mathrm{a}$ and $\mathrm{b}$ shows the SEM micrographs at $1450^{\circ} \mathrm{C}$ of CFQ samples. Isolated large pores (figure $7 \mathrm{~b}$ ) and fine pores
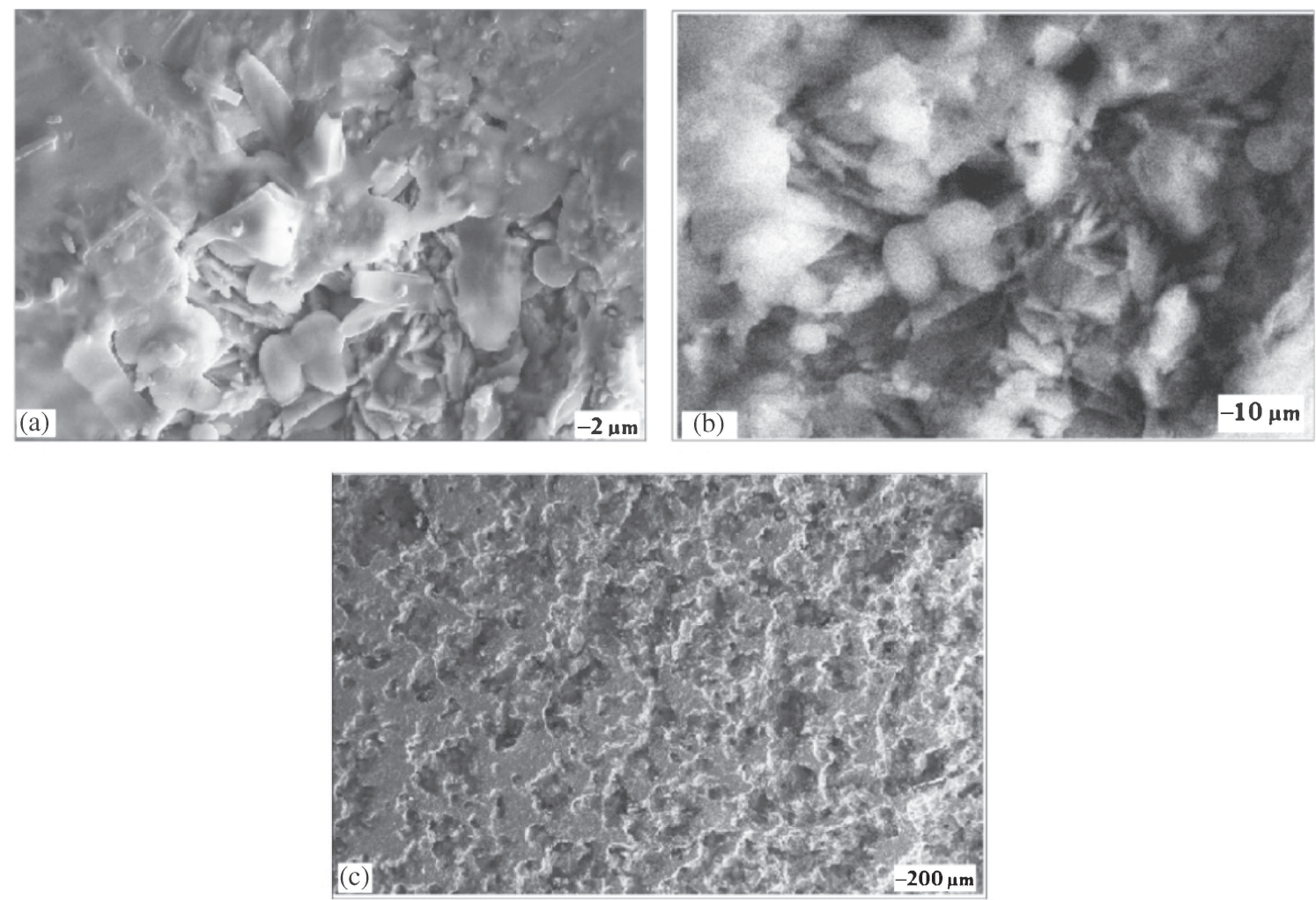

Figure 6. SEM photograph of CAQ at $1450^{\circ} \mathrm{C}$ at different locations. 

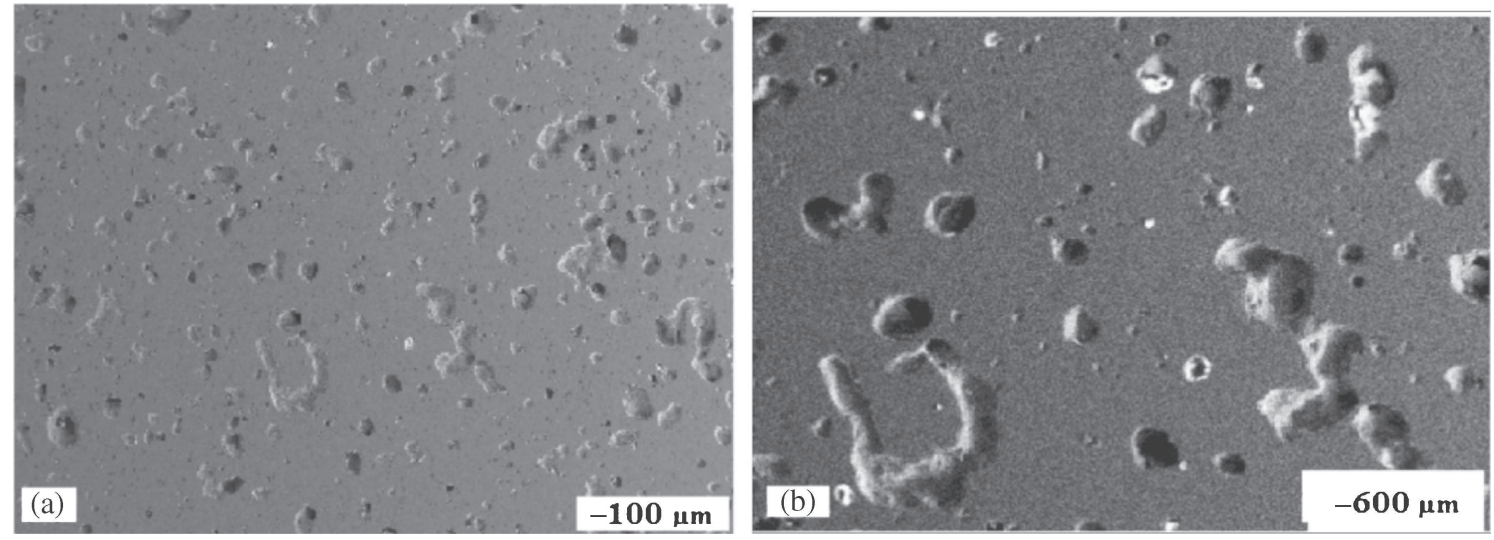

Figure 7. SEM photograph of CFQ at $1450^{\circ} \mathrm{C}$ at different locations.

in large numbers (figure 7a) are observed in these micrographs. Although the samples are vitrified $(\leq 2.0 \%)$ but close pores are present in the sample. Similar type of structure with a lot of pores was observed by the present authors in their industrial solid wastes incorporated work. ${ }^{16}$

\section{Conclusion}

In this study, anorthite-based porcelain was produced by conventional technique of compaction and firing from two compositions. Out of these two compositions, the samples containing aluminous cement, feldspar and quartz showed highest densification, lowest porosity and highest flexural strength at $1450^{\circ} \mathrm{C}$. But another composition containing $\mathrm{Ca}(\mathrm{OH})_{2}, \mathrm{Al}(\mathrm{OH})_{3}$ and quartz showed less densification and inadequate strength even at $1450^{\circ} \mathrm{C}$. This composition requires higher temperature for vitrification. Anorthite as only crystalline phase was found in both the samples. The lowest coefficient of expansion value of CFQ is expected to have better heat stability thus suitable for cooking ware body.

\section{Acknowledgements}

We thank the Director, CSIR - Central Glass and Ceramic Research Institute, for his kind permission to publish this paper. We also wish to thank SEM and XRD sections for their help in characterizing the samples.

\section{References}

1. Gdula R A 1971 Am. Ceram. Soc. Bull. 50555

2. Kurama S and Ozel E 2004 Ceram. Int. 35827

3. Correia R N 2003 Biomaterials 241317

4. Kavalci S, Yalamac E and Akkurt S 2008 Ceram. Int. 341629

5. Cheng X, Shanjun Ke, Wang Q, Wang H, Shui A and Liu P 2012 Ceram. Int. 383327

6. Tai W, Kimurab K and Jinnaic K 2002 J. Eur. Ceram. Soc. 22 463

7. Mergena A and Aslanog Z 2003 Ceram. Int. 29667

8. Shanjun Ke, Cheng X, Wang Y, Wang Q and Wang H 2013 Ceram. Int. 394953

9. Pal M and Das S K 2012 Indoceram AIMPA 129

10. Pal M and Das S K 2013 Interceram 120

11. Hillebrand W F and Lundell G E F 1953 Applied inorganic analysis 2nd ed (New York: Wiley) p 507

12. Rietveld H M 1969 J. Appl. Crystallogr. 265

13. Young R A 1995 In Introduction to Rietveld method, The Rietveld method (ed) R A Young (Oxford: Oxford University Press) Chapter 1, p. 298

14. Goswami A P, Poddar R K, Khattry D K and Lodha A C 2000 In Refractories and furnaces - new options and new values (eds) G Banerjee and S K Das et al (Allied Publishers) ISBN 81-7764-109-3, p. 145

15. Marques V M F, Tulyaganov D U, Aguthopoulos S, Gataulin V K, Kothiyal G P and Ferreira J 2006 J. Eur. Ceram. Soc. 26 2503

16. Das S K, Pal M, Ghosh J, Pathi K V and Mondal S 2013 Trans. Indian. Inst. Met. $\mathbf{6 6} 213$ 